\title{
Gradients in Susceptibility and Resistance Mechanisms of Buddleia L. Taxa to the Two-spotted Spider Mite (Tetranychus urticae Koch)
}

\author{
Jeffrey H. Gillman, ${ }^{1}$ Michael A. Dirr, ${ }^{2}$ and S. Kristine Braman ${ }^{3}$ \\ Department of Horticulture, The University of Georgia, Athens, GA 30602
}

\begin{abstract}
AdDitional INDEX wORDs. butterfly bush, host plant resistance, insect resistance, trichome, pubescence
Abstract. Buddleia taxa were assessed for two-spotted spider mite (Tetranychus urticae Koch) resistance using a leaf disk bioassay, a novel shell vial bioassay and a field trial. Leaf pubescence and chemistry were examined for their role in two-spotted spider mite resistance. Results from bioassays and field sampling identified highly resistant taxa including $B$. fallowiana Balif. 'Alba' and B.davidii X B. fallowiana Franch. 'Cornwall Blue' as well as susceptible taxa including B. davidii Franch. 'African Queen' and B. lindleyana Fort. ex Lindl. 'Gloster'. The shell vial bioassay was an accurate predictor of field resistance to spider mite. Leaf pubescence was quantified by calculating the collective length of trichome branches per square millimeter of leaf surface area [effective branch length (EBL)]. EBL values ranged from 39 to $162 \mathrm{~mm} \cdot \mathrm{mm}^{-2}$ of leaf surface area among Buddleia taxa. Resistance was positively correlated with increased pubescence. Removal of pubescence by peeling resulted in increased oviposition of two-spotted spider mites. Exposing female two-spotted spider mites to a methylene chloride extract of $B$. davidii $x$ B. fallowiana 'Cornwall Blue' using a modified shell vial bioassay resulted in reduced oviposition and a methylene chloride extract of B. davidii 'African Queen' resulted in no difference in oviposition when compared with a control. While pubescence is the best indicator of resistance to the two-spotted spider mite in Buddleia taxa, it is possible that defensive compounds are involved.
\end{abstract}

Buddleia taxa, butterfly bushes, are popular ornamental shrubs grown for their large fragrant inflorescences that attract nectar feeding butterflies to a garden. The most damaging pest of Buddleia species is the two-spotted spider mite, Tetranychus urticae Koch, (Maunder, 1987) whose feeding causes stippling, chlorosis, and leaf abscision (Metcalf and Metcalf, 1993), and results in plants that are aesthetically displeasing and difficult to market.

The two-spotted spider mite is one of the most damaging arthropods to nursery and greenhouse crops in the southeast (Hudson et al., 1996; Baker, 1980) and requires frequent pesticide inputs for control (Hudson et al., 1996). Many crops, both horticultural and agronomic, have been examined for resistance to the two-spotted spider mite including Gossypium hirsutum L. (Schuster et al., 1972), Cucumis sativus L. (Knipping et al., 1975), Rubus idaeus L. (Wilde et al., 1991), and Fragaria sp. L. (Ferrer et al., 1993). Woody landscape ornamentals, such as the shrubby Buddleia taxa, have not been evaluated for their resistance to the two-spotted spider mite. Selection of resistant taxa would prove economically and aesthetically beneficial to growers and gardeners.

The ability of Buddleia species to resist infestation by arthropod pests has been noted in various literature sources (Dirr, 1998; Owen and Whiteway, 1980). This resistance is thought to be associated with plant chemistry (Owen and Whiteway, 1980), which is supported by research showing that, at least in the case of $B$. lindleyana Fort. ex Lindl., compounds toxic to arthropods are present (Chin et al., 1947). Many Buddleia taxa, including B. davidii, contain novel sesquiterpenes and alkaloids (Roder et al., 1985; Stermitz and Harris, 1985; Yoshida et al., 1978). The ability of these compounds in Buddleia

Received for publication 27 Apr. 1998. Accepted for publication 16 Nov. 1998. We thank Hazel Wetztein for technical assistance. Use of trade names does not imply endorsement of products named or criticism of ones not mentioned. The cost of publishing this paper was defrayed in part by the payment of page charges. Under postal regulations, this paper therefore must be hereby marked advertisement solely to indicate this fact.

${ }^{1}$ Assistant professor, Department of Horticultural Science, University of Minnesota, St. Paul, MN 55108.

${ }^{2}$ Professor, Department of Horticulture, University of Georgia, Athens, GA 30602. ${ }^{3}$ Associate professor, Department of Entomology, Georgia Experiment Station, Griffin, GA 30223. taxa to reduce arthropod feeding, however, is unknown although extracts of B. madigascariensis Lam. (Shoeb et al., 1991) have been shown to be toxic to mollusks. Glandular trichomes that may contain defensive compounds are present on the leaves of Buddleia species (Rogers, 1986).

A second mechanism that may affect arthropod herbivory in Buddleia taxa is the presence of highly branched, nonglandular trichomes (Rogers, 1986). Although the ability of these trichomes to prevent herbivory is not well characterized, there is evidence that they are defensive structures that limit arthropodfeeding. Cleopusjaponicus Wingelmuller, a weevil that is host specific to Buddleia, avoids the trichomitous undersurface of B. davidii leaves (Zhang et al., 1993) and feeds on the upper surface. This feeding behavior indicates that mechanisms present on the underside of Buddleia leaves, most probably trichomes, are affecting the weevil's ability to feed successfully on this portion of the leaf.

Standard assays for assessing the relative susceptibility of particular plants to the two-spotted spider mite frequently consist of leaf disk bioassays (de Ponti, 1977a; Ferrer et al., 1993; Wilde et al., 1991). Leaf disk bioassays rapidly provide information regarding the effects of cultivar, pesticides, and even nutrient regimes, on small arthropods such as spider mites. These assays, however, are confounded when nonpreference effects cause spider mites to exit leaf disks of plants that they normally infest despite the presence of viscous materials surrounding, and intended to keep mites on, the experimental surface (Aina et al., 1972; Knipping et al., 1975; Mansour and Karchi, 1990; Wilde et al., 1991). The exit of spider mites from leaf disks creates a confounding effect when counting the number of eggs laid by female mites over time, the criterion most commonly used for assessing resistance (de Ponti, 1977a; Ferrer et al., 1993; Wilde et al., 1991). Although this problem has been rectified by certain pesticide bioassays in which compounds are applied directly to the surface of a sealed container holding the spider mites (Kabir et al., 1996), these assays are not practical for testing leaf tissue or for assessing any variable except mite mortality. A second confounding factor associated with standard leaf disk bioassays is the orientation of leaf disks in a fashion that is unfamiliar to spider mites who commonly feed in an inverted position on the underside of leaves. Most leaf disk 
bioassays allow mites to feed on disks which have been placed upside-down in a petri dish, thus forcing the mite to feed in an upright orientation. The problem of incorrect orientation of leaf disks has been addressed by researchers, working with the broad mite, by placing leaf disks onto solidifying agar and then inverting the entire plate (Herron et al., 1996). This system controls orientation, but still offers mites the opportunity to exit the experimental surface onto a medium which could cause mortality.

The objective of the current research was to test the hypothesis that there are differences in two-spotted spider mite resistance among Buddleia taxa and, having demonstrated resistance, to determine the effects of Buddleia leaf pubescence and leaf surface compounds on two-spotted spider mite resistance.

\section{Materials and Methods}

LeVElS OF RESISTANCE AMONG Buddleia TAXA. Two-spotted spi- der mite resistance was examined among 37 Buddleia species and cultivars with a preliminary leaf disk bioassay. Due to the frequency of mites exiting leaf disks in the preliminary leaf disk bioassay, a second bioassay was developed, termed a shell vial bioassay, which permitted orientation of the leaf surface in its natural position for spider mite feeding, as well as excluding the need for a barrier created by viscous compounds. Nine taxa with extreme resistance or susceptibility to the two-spotted spider mite, based on the preliminary leaf disk bioassay, were selected for further study using the shell vial bioassay. The nine taxa tested with the shell vial bioassay and two others were evaluated in a field trial.

LEAF DISK BIOASSAY. Five leaf disks, $1.2 \mathrm{~cm}$ in diameter, were cut from fully expanded young leaves of Buddleia taxa (Table 1) using a cork borer. All Buddleia taxa were greenhouse grown, watered as needed, and fertilized with Nutricote Total 17-7-8 (17N-3.0P-6.7K plus micronutrients) (Plantco Inc., Ontario, Canada) slow release fertilizer. Five leaf disks, all from different

Table 1. Buddleia taxa susceptibility to the two-spotted spider mite as measured by mites remaining on leaf disks and number of eggs laid by 4 female spider mites on leaf disks after 48 and $96 \mathrm{~h}$ (error $\mathrm{df}=148 ; 48$-h mites $\mathrm{F}=2.58, P<0.01 ; 48$-h eggs $\mathrm{F}=2.28, P<0.01 ; 96$-h mites $\mathrm{F}=1.85, P<$ $0.01 ; 96$-h eggs $\mathrm{F}=2.68, P<0.01)$.

\begin{tabular}{|c|c|c|c|c|}
\hline \multirow{3}{*}{$\begin{array}{l}\text { Species } \\
\text { or cultivar }\end{array}$} & \multicolumn{4}{|c|}{ Time (h) } \\
\hline & \multicolumn{2}{|c|}{48} & \multicolumn{2}{|c|}{96} \\
\hline & Mites/disk & Eggs/disk & Mites/disk & Eggs/disk \\
\hline B. lindleyana Fort. Ex Lindl Gloster & $2.0 \mathrm{abc}^{\mathrm{z}}$ & $7.6 \mathrm{ab}$ & 2.2 abcd & $8.2 \mathrm{abc}$ \\
\hline B. davidii Franch. African Queen & $2.4 \mathrm{ab}$ & 3.4 abcd & $2.4 \mathrm{a}$ & $7.0 \mathrm{a}$ \\
\hline B. lindleyana Mayflower & 1.4 abcde & 5.6 abcde & 1.0 abcdef & 6.8 abcdef \\
\hline B. hemsleyana Hemsl. & 1.8 abcde & $3.6 \mathrm{abc}$ & 1.0 abcdef & $6.4 \mathrm{ab}$ \\
\hline B. davidii White Profusion & 1.4 bcdef & $5.4 \mathrm{abc}$ & 0.6 defg & $6.2 \mathrm{abcd}$ \\
\hline B. colvilei Hook. f \& Thoms. & $2.4 \mathrm{ab}$ & $5.2 \mathrm{a}$ & 1.4 abcdef & $5.6 \mathrm{ab}$ \\
\hline B. globosa Hope. & $2.2 \mathrm{ab}$ & $5.0 \mathrm{ab}$ & 1.4 abcdef & 4.8 abcd \\
\hline B. japonica Hemsl. & 1.0 cdefg & 2.6 abcd & 1.2 abcdef & 4.2 abcde \\
\hline B. davidii White Harlequin & $2.0 \mathrm{abc}$ & 2.6 abcde & $1.6 \mathrm{abcd}$ & 3.8 abcd \\
\hline B. salvifolia $\mathrm{L}$. & 1.6 abcde & 3.2 abcd & 1.6 abcdef & 3.2 abcdefg \\
\hline B. davidii var. nanhoensis Petite Plum & $2.0 \mathrm{abcd}$ & 2.4 abcdef & $0.4 \mathrm{gf}$ & 3.0 bcdefghi \\
\hline B. asiatica Lour. & $2.2 \mathrm{ab}$ & 2.0 abcde & $2.0 \mathrm{abc}$ & 2.2 abcdefgh \\
\hline B. davidii Miss Ellen & $3.2 \mathrm{a}$ & 1.6 abcdef & $1.8 \mathrm{abcd}$ & 2.2 bcdefghi \\
\hline B. nivea Duthie. & $2.0 \mathrm{abc}$ & 1.4 abcdef & 1.8 abcd & 1.8 bcdefghi \\
\hline B. davidii Fascination & $1.8 \mathrm{abcd}$ & 1.0 bcdef & 1.8 abcd & 1.8 cdefghi \\
\hline B. davidii Summer Beauty & $0.6 \mathrm{efg}$ & 0.6 def & 0.8 abcdef & 1.6 bcdefghi \\
\hline B. macrostachya Benth. in Wall. & $2.2 \mathrm{ab}$ & $0.6 \mathrm{def}$ & $2.2 \mathrm{ab}$ & 1.4 cdefghi \\
\hline B. davidii Mary's White & 1.2 bcdef & $0.8 \mathrm{cdef}$ & 0.8 cdefg & 1.4 cdefghi \\
\hline B. weyeriana Weyer. Honeycomb & 1.2 bcdef & 0.6 def & 0.8 cdefg & 1.4 cdefghi \\
\hline B. davidii Bonnie & 1.2 abcde & $0.2 \mathrm{ef}$ & 1.0 abcdef & 1.2 defghi \\
\hline B. davidii Dubonnet & 1.6 abcde & 0.4 def & 0.8 cdefg & 1.2 cdefghi \\
\hline B. davidii Black Knight & 1.0 cdefg & 0.6 def & 0.8 cdefg & 1.0 efghi \\
\hline B. crispa Benth. & $2.0 \mathrm{abcd}$ & 0.4 def & 1.6 abcde & 0.8 defghi \\
\hline B. davidii Pink Charmer & 1.2 abcde & 0.2 ef & 1.4 abcde & 0.6 efghi \\
\hline B. davidii Pink Charming & 1.0 cdefg & $0.8 \mathrm{cdef}$ & 1.0 bcdef & 0.6 fghi \\
\hline B. davidii Border Beauty & 0.8 defg & $0.2 \mathrm{ef}$ & 1.0 bcdef & 0.4 ghi \\
\hline B. davidii Empire Blue & 0.6 efg & $0.2 \mathrm{ef}$ & 0.8 cdefg & 0.4 fghi \\
\hline B. fallowiana Balf. Alba & $0.8 \mathrm{defg}$ & $0.6 \mathrm{def}$ & $0.6 \mathrm{efg}$ & 0.4 fghi \\
\hline B. davidii $\times$ B. fallowiana Lochinch & $0.8 \mathrm{efg}$ & $0.0 \mathrm{f}$ & $0.4 \mathrm{fg}$ & 0.4 ghi \\
\hline B. davidii Pink Delight & $1.2 \mathrm{bcdef}$ & $0.2 \mathrm{ef}$ & $1.0 \mathrm{abcdef}$ & $0.2 \mathrm{hi}$ \\
\hline B. davidii Royal Red & $0.4 \mathrm{fg}$ & 0.2 ef & $0.4 \mathrm{fg}$ & $0.2 \mathrm{hi}$ \\
\hline B. davidii Nanho White & 1.4 abcde & $0.0 \mathrm{f}$ & 1.4 abcde & $0.0 \mathrm{i}$ \\
\hline B. davidii Burgundy & 1.8 abcde & $0.0 \mathrm{f}$ & 1.2 abcdef & $0.0 \mathrm{i}$ \\
\hline B. davidii Charming & 1.4 bcdef & $0.0 \mathrm{f}$ & $1.0 \mathrm{defg}$ & $0.0 \mathrm{i}$ \\
\hline B. weyeriana Sungold & $0.2 \mathrm{~g}$ & $0.0 \mathrm{f}$ & 0.6 efg & $0.0 \mathrm{i}$ \\
\hline B. davidii $\times$ B. fallowiana Cornwall Blue & 0.8 defg & $0.0 \mathrm{f}$ & $0.4 \mathrm{fg}$ & $0.0 \mathrm{i}$ \\
\hline B. davidii Ile de France & $0.2 \mathrm{~g}$ & $0.0 \mathrm{f}$ & $0.0 \mathrm{~g}$ & $0.0 \mathrm{i}$ \\
\hline
\end{tabular}

${ }^{\mathrm{z}}$ Means in a column followed by the same letter are not significantly different $(\alpha=0.05)$ using Fisher's protected LSD test. 
Table 2. Eggs laid by five female two-spotted spider mites on nine Buddleja taxa after $96 \mathrm{~h}$ in shell vial (error df $=168, \mathrm{~F}=15.49, P<$ $0.01)$.

\begin{tabular}{lc}
\hline \hline Species or cultivar & Eggs laid (no.) \\
\hline B. davidii African Queen & $145.5 \mathrm{a}^{\mathrm{z}}$ \\
B. lindleyana Gloster & $74.5 \mathrm{~b}$ \\
B. davidii Ile de France & $59.8 \mathrm{~b}$ \\
B. weyeriana Sungold & $54.3 \mathrm{~b}$ \\
B. davidii Black Knight & $47.0 \mathrm{bc}$ \\
B. davidii Miss Ellen & $32.5 \mathrm{~cd}$ \\
B. davidii Nanho White & $28.1 \mathrm{~cd}$ \\
B. davidii X B. fallowiana Cornwall Blue & $20.7 \mathrm{de}$ \\
B. fallowiana Alba & $9.7 \mathrm{e}$
\end{tabular}

${ }^{\mathrm{z}}$ Means followed by the same letter are not significantly different $(\alpha=$ 0.05 ) using Fisher's protected LSD test.

taxa, were placed top side down onto 9-cm circles of \#1 filter paper (Whatman, Kent, England) that had been placed into glass petri dishes (9 $\mathrm{cm}$ in diameter) and moistened with $2 \mathrm{~mL}$ of distilled water. Leaf disks were ringed with petroleum jelly and four adult female two-spotted spider mites were placed onto each disk. Mites came from a culture raised on bean plants (Phaseolus vulgaris L. 'Kentucky Wonder' and 'White Half Runner'). Petri dishes were sealed with parafilm to reduce desiccation of leaf disks and were subsequently placed into an incubator at $25 \pm 1{ }^{\circ} \mathrm{C}$ with a photoperiod of $12 \mathrm{~h}$ light $\left(24 \pm 3 \mu \mathrm{mol} \cdot \mathrm{m}^{-2} \cdot \mathrm{s}^{-1}\right): 12 \mathrm{~h}$ dark. Leaf disks were evaluated 48 and $96 \mathrm{~h}$ after the introduction of mites, at which time the number of mites remaining and number of eggs laid on each disk were recorded. Data were transformed [sqrt (x)] and subjected to analysis of variance (version 6.10; SAS, Cary, N.C.). Mean separation was accomplished using Fisher's protected LSD test.

Shell Vial bioAssay. Nine Buddleia taxa (Table 2), selected on the basis of results from the leaf disk bioassay, were tested for twospotted spider mite resistance using a shell vial bioassay. These taxa were grown under greenhouse conditions and were watered and fertilized as needed with 200 ppm N as Peters 20-10-20 (20N-4.0P17K) (Scotts-Sierra Hort. Prod. Co. Marysville, Ohio). Leaves were selected randomly from populations of not less than five individual Buddleia from each taxon. Five-dram glass shell vials $(27.25 \mathrm{~mm}$ in diameter $\times 55 \mathrm{~mm}$ in length) with polyethylene two piece closures (Fisher Scientific, Pittsburgh, Pa.) were modified by removing the top from the cap of the two-piece closure and making 16 evenly spaced vertical cuts along the upper portion of the cap that surrounded the orifice revealed by removing the top (Fig. 1). Five female twospotted spider mites, collected from the same culture as that used for the preliminary leaf disk bioassay, were placed into the glass portion of the shell vial using a horse-hair brush. A young fully expanded leaf from the Buddleia taxon was placed bottom side down over the mouth of the shell vial, exposing the central basal section of the leaf to the mites. A piece of damp filter paper $(\approx 5 \times 2 \mathrm{~cm})$ was then folded into the cap and the cap was placed over the leaf and the bottom portion of the shell vial. Parafilm was wrapped around the cap to ensure a firm closure between the cap and the shell vial. Shell vials were placed into an illuminated incubator at $25 \pm 1{ }^{\circ} \mathrm{C}$ with a photoperiod of $12 \mathrm{~h}$ light $\left(24 \pm 3 \mu \mathrm{mol} \cdot \mathrm{m}^{-2} \cdot \mathrm{s}^{-1}\right) / 12 \mathrm{~h}$ dark. After $96 \mathrm{~h}$, the number of eggs laid per shell vial was determined by examining with a dissecting scope $(20 \times)$ the portion of the leaf that had been exposed to the spider mites. Four blocks which were separated by time and which included five shell vials each were run for all Buddleia taxa. Data were transformed [sqrt (x)] and subjected to analysis of variance (version 6.10; SAS). Mean separation was accomplished using Fisher's protected LSD test.

Field TRIal. Eleven different Buddleia taxa, including all of the taxa evaluated using the shell vial bioassay as well as $B$. davidii Franch. 'Pink Delight' and 'Bonnie', were planted, with two replications each, into four randomized blocks at the University of Georgia Horticulture Farm in Oconee County, Ga., in July 1996. Plants that died over the ensuing winter were replanted in March, 1997. Plants were fertilized with 10-10-10 (10N-4.0P-8.5K) (Gold Kist, Inc., Atlanta, Ga.) and watered as needed using drip irrigation. Naturally occurring mite and beneficial arthropod populations were sampled from all of the replications on 8 May and every $10 \mathrm{~d}( \pm 1 \mathrm{~d})$ from 14 May through 5 Sept. Sampling was accomplished by counting the number of two-spotted spider mites and spider mite eggs on a $6-\mathrm{cm}^{2}$ section of the basal portion of five mature leaves collected randomly from each of the shrubs, except on 8 May when only three leaves per shrub were sampled. Leaves were collected from the second to fourth fully expanded leaves below shoot termini. Data were transformed [sqrt (x)] and subjected to analysis of variance (version 6.10; SAS). Mean separa-

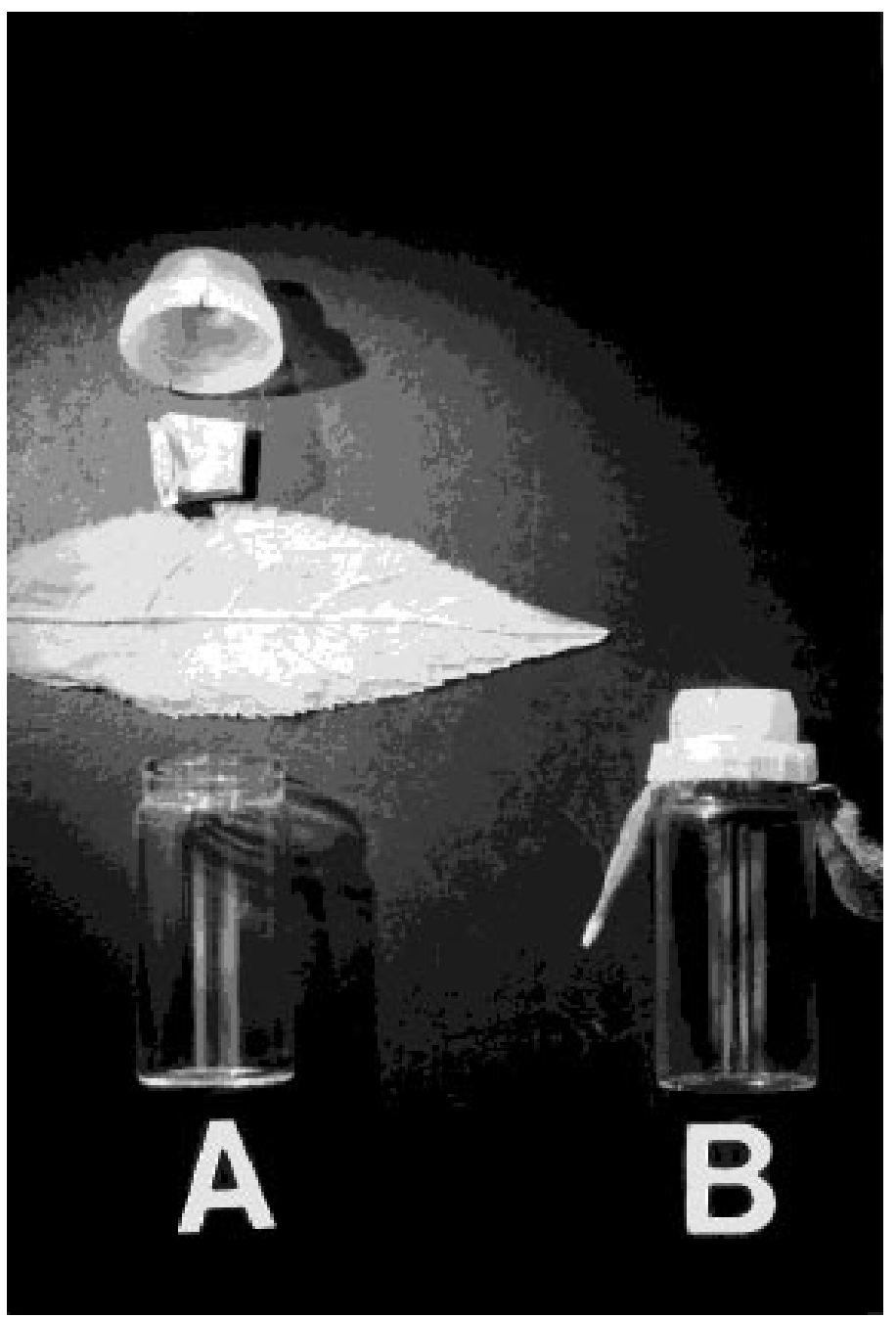

Fig. 1. (A) Components of apparatus used for shell vial bioassays constructed from a 5-dram shell vial with corresponding two piece polyethylene closure: The cap from the polyethylene two piece closure is modified by removing the top and cutting flanges along the remaining orifice. Moist filter paper $(5 \times 2 \mathrm{~cm})$ is then folded into the cap to provide moisture for the experimental leaf which is placed bottom side down over the 5-dram glass shell vial that contains five female twospotted spider mites. The cap is then snapped over the leaf and the opening of the glass vial and the apparatus is sealed with parafilm. (B) Assembled apparatus for shell vial bioassay. The modified shell vial bioassay is the same as above except that a bean leaf is used as the food source and a treated tissue inundated with holes separates the leaf from the mites. 
Table 3. Two-spotted spider mite motile stages (adults and nymphs) and eggs found per $6 \mathrm{~cm}^{2}$ of leaf area on Buddleia taxa from 8 May through 13 June field trials (error $\mathrm{df}=2148$ : average mites $\mathrm{F}=48.16, P<0.01$, average eggs $\mathrm{F}=30.42, P<0.01$ ).

\begin{tabular}{|c|c|c|c|c|c|c|c|c|c|c|c|c|}
\hline \multirow[b]{2}{*}{ Cultivar } & \multicolumn{2}{|c|}{8 May } & \multicolumn{2}{|c|}{14 May } & \multicolumn{2}{|c|}{25 May } & \multicolumn{2}{|c|}{3 June } & \multicolumn{2}{|c|}{13 June } & \multicolumn{2}{|c|}{ Avg } \\
\hline & Mites & Eggs & Mites & Eggs & Mites & Eggs & Mites & Eggs & Mites & Eggs & Mites & Eggs \\
\hline & \multicolumn{12}{|c|}{ Number } \\
\hline Gloster $^{y}$ & $4.0 \mathrm{a}^{\mathrm{z}}$ & $63.5 \mathrm{a}$ & $4.6 \mathrm{a}$ & $25.9 \mathrm{a}$ & $5.7 \mathrm{a}$ & $13.7 \mathrm{bc}$ & $7.9 \mathrm{a}$ & $12.6 \mathrm{ab}$ & $1.0 \mathrm{~cd}$ & $3.2 \mathrm{ab}$ & $4.8 \mathrm{a}$ & $19.9 \mathrm{a}$ \\
\hline Pink Delight ${ }^{\mathrm{x}}$ & $3.1 \mathrm{ab}$ & $14.0 \mathrm{~b}$ & $3.2 \mathrm{ab}$ & $0.9 \mathrm{~b}$ & $4.1 \mathrm{ab}$ & $8.1 \mathrm{~cd}$ & $4.0 \mathrm{bcd}$ & $4.0 \mathrm{bc}$ & $1.7 \mathrm{ab}$ & $1.5 \mathrm{ab}$ & $3.3 \mathrm{~b}$ & $5.5 \mathrm{c}$ \\
\hline African Queen ${ }^{\mathrm{x}}$ & $3.0 \mathrm{ab}$ & $21.1 \mathrm{~b}$ & $1.2 \mathrm{~cd}$ & $5.9 \mathrm{~b}$ & $5.5 \mathrm{a}$ & $22.2 \mathrm{ab}$ & $4.4 \mathrm{bc}$ & $18.1 \mathrm{a}$ & $0.9 \mathrm{bcd}$ & $6.9 \mathrm{a}$ & $3.2 \mathrm{~b}$ & $14.8 \mathrm{~b}$ \\
\hline Bonnie $^{x}$ & $0.3 \mathrm{~d}$ & $0.2 \mathrm{~b}$ & $1.8 \mathrm{bc}$ & $2.8 \mathrm{~b}$ & $1.9 \mathrm{~cd}$ & $6.3 \mathrm{~cd}$ & $6.0 \mathrm{ab}$ & $19.7 \mathrm{a}$ & $2.6 \mathrm{a}$ & $6.7 \mathrm{a}$ & $2.6 \mathrm{~cd}$ & $8.0 \mathrm{c}$ \\
\hline Sungold $^{\mathrm{w}}$ & $1.3 \mathrm{~cd}$ & $1.0 \mathrm{~b}$ & $2.1 \mathrm{bc}$ & $1.4 \mathrm{~b}$ & $3.1 \mathrm{bc}$ & $26.2 \mathrm{a}$ & $3.6 \mathrm{bcd}$ & $16.9 \mathrm{a}$ & $1.0 \mathrm{~cd}$ & $3.8 \mathrm{ab}$ & $2.4 \mathrm{bc}$ & $12.3 \mathrm{~b}$ \\
\hline Ile de France ${ }^{x}$ & $2.6 \mathrm{abc}$ & $2.5 \mathrm{~b}$ & $1.3 \mathrm{~cd}$ & $1.2 \mathrm{~b}$ & $2.5 \mathrm{bcd}$ & $3.9 \mathrm{~d}$ & $1.3 \mathrm{cde}$ & $2.6 \mathrm{bc}$ & $0.2 \mathrm{~cd}$ & $0.1 \mathrm{~b}$ & $1.6 \mathrm{cde}$ & $2.3 \mathrm{~cd}$ \\
\hline Nanho White ${ }^{\mathrm{x}}$ & $1.6 \mathrm{bcd}$ & $0.7 \mathrm{~b}$ & $1.9 \mathrm{bc}$ & $1.7 \mathrm{~b}$ & $1.9 \mathrm{~cd}$ & $1.6 \mathrm{~d}$ & $0.8 \mathrm{de}$ & $1.2 \mathrm{c}$ & $0.8 \mathrm{~cd}$ & $0.4 \mathrm{~b}$ & $1.5 \mathrm{def}$ & $1.3 \mathrm{de}$ \\
\hline Black Knight $^{\mathrm{x}}$ & $0.3 \mathrm{~d}$ & $0.0 \mathrm{~b}$ & $0.9 \mathrm{~cd}$ & $0.7 \mathrm{~b}$ & $2.2 \mathrm{~cd}$ & $3.8 \mathrm{~d}$ & $2.2 \mathrm{cde}$ & $3.8 \mathrm{bc}$ & $0.4 \mathrm{~cd}$ & $0.5 \mathrm{~b}$ & $1.4 \mathrm{def}$ & $2.2 \mathrm{~cd}$ \\
\hline Cornwall Blue $^{v}$ & $1.2 \mathrm{~cd}$ & $0.9 \mathrm{~b}$ & $1.9 \mathrm{bc}$ & $0.7 \mathrm{~b}$ & $1.4 \mathrm{de}$ & $5.1 \mathrm{~cd}$ & $0.8 \mathrm{de}$ & $1.2 \mathrm{c}$ & $0.1 \mathrm{~cd}$ & $0.1 \mathrm{~b}$ & $1.0 \mathrm{ef}$ & $1.8 \mathrm{~d}$ \\
\hline Miss Ellen ${ }^{\mathrm{x}}$ & $0.2 \mathrm{~d}$ & $0.0 \mathrm{~b}$ & $0.6 \mathrm{~cd}$ & $0.3 \mathrm{~b}$ & $1.1 \mathrm{de}$ & $2.6 \mathrm{~d}$ & $1.1 \mathrm{de}$ & $1.5 \mathrm{c}$ & $0.2 \mathrm{~cd}$ & $0.5 \mathrm{~b}$ & $0.7 \mathrm{f}$ & $1.2 \mathrm{de}$ \\
\hline $\mathrm{Alba}^{\mathrm{u}}$ & $0.0 \mathrm{~d}$ & $0.0 \mathrm{~b}$ & $0.0 \mathrm{~d}$ & $0.0 \mathrm{~b}$ & $0.0 \mathrm{e}$ & $0.0 \mathrm{~d}$ & $0.0 \mathrm{e}$ & $0.0 \mathrm{c}$ & $0.0 \mathrm{~d}$ & $0.0 \mathrm{~b}$ & $0.0 \mathrm{~g}$ & $0.0 \mathrm{e}$ \\
\hline
\end{tabular}

${ }^{\mathrm{z}}$ Means in a column followed by the same letter are not significantly different $(\alpha=0.05)$ using Fisher's protected LSD test.

y Buddleia lindleyana.

${ }^{\mathrm{x}}$ Buddleia davidii.

${ }^{\mathrm{w}}$ Buddleia weyeriana.

${ }^{\mathrm{v}}$ Buddleia davidii.x B. fallowiana.

uBuddleia fallowiana.

tion was accomplished using Fisher's protected LSD test.

QuANTIFICATION OF PUBESCENCE. Five fully expanded young leaves were selected randomly from populations of at least five Buddleia plants of the same taxa as investigated in the shell vial bioassay. Plants were grown as described for the shell vial bioassay. Pubescence was quantified by removing epidermal peels from the basal central portion of the underside of each leaf and examining them, using a compound microscope (100×) with a micrometer, to determine the length of branches originating from dendritic trichomes as well as the number of trichome branch points per unit area. Sixteen branches were measured and four observations on the number of branches per $0.13 \mathrm{~mm}^{2}$ were tabulated per leaf. Data were then converted to millimeters of trichome branches per square millimeter of leaf surface area by multiplying: (average length of branches $) \times($ average number of branch points per square millimeter) $\times$ [number of branches originating from each branch point (four, except for B. lindleyana, which has six)]. The result was termed Effective Branch Length (EBL). Branch lengths and number of branch points per square millimeter were confirmed using electron microscopy. EBL was then correlated with resistance results from the previously mentioned shell vial bioassay using regression analysis (version 6.10; SAS). Significant differences in branch length and number of branches per square millimeter were determineded using Fisher's protected LSD test (version 6.10; SAS).

REMOVAL OF TRICHOMES AND BIOASSAY OF MITES ON TRICHOMELESS PLANTS. The leaves of four Buddleia taxa, representing a range of resistance from most to least susceptible, including $B$. davidii 'African Queen', 'Black Knight', and 'Miss Ellen' and B. davidii x B. fallowiana Balif. 'Cornwall Blue', were used to determine whether pubescence has an effect on resistance to two-spotted spider mite. A novel bioassay was developed to test the effect of pubescence on spider mite fecundity. Pubescence was removed from young fully expanded leaves of Buddleia taxa by applying Freeman's facial peel (Freeman's Cosmetic Co., Beverly Hills, Calif.) to the undersurface of leaves and allowing the peel to dry for $\approx 1 \mathrm{~h}$. before being removed to expose the epidermal layer of the leaves. Treatments included complete pubescence removal and no pubescence removal. Five female two-spotted spider mites were allowed to oviposit for $96 \mathrm{~h}$ on experimental leaves using a shell vial bioassay as previously described. Two blocks, each including five experimental shell vials of each treatment and taxon, were run. Differences in two-spotted spider mite egg deposition between treatments within each taxon were evaluated using Student's $t$ test (version 6.10; SAS).

EFFECT OF LEAF SURFACE COMPOUNDS ON FECUNDITY. The ability of leaf surface compounds present in Buddleia taxa to reduce twospotted spider mite egg laying was assessed via the following bioassay, termed a modified shell vial bioassay. Compounds soluble in methylene chloride were extracted from the leaves of $B$. davidii 'African Queen' and B. davidii X B. fallowiana 'Cornwall Blue', by dipping fully expanded young leaves $\left(160 \pm 5 \mathrm{~cm}^{2}\right)$ into $10 \mathrm{~mL}$ of methylene chloride for ten seconds. This extract $(0.56$ $\mathrm{ml}$ ) was applied to $9-\mathrm{cm}^{2}$ sections of tissue (Kimwipes; KimberlyClark, Roswell, Ga.) at the same concentration as it had been on the surface of the leaf. Each tissue was punctured at a density of 22.5 holes $/ \mathrm{cm}^{2}$ by pushing a hypodermic needle $1 \mathrm{~mm}$ in diameter (19 gauge) through a cardboard template before the application of methylene chloride and extract. Holes allowed mites to cross from the glass shell vial to a food source while forcing them to come in contact with the treated tissue. Treated tissues were placed, with the side opposing the direction of needle entry down, over the underside of a fully expanded young leaf removed from the first leaf pair of Phaseolus vulgaris 'White Half Runner' (a common host plant of $T$. urticae), and these leaves were, in turn, placed tissue side down over a shell vial which contained five female two spotted spider mites (Fig. 1). Shell vial closures were modified as mentioned previously. After $96 \mathrm{~h}$ the number of eggs laid per shell vial were counted. Two blocks, each including five shell vials of both treatments and a control, methylene chloride (without plant extract) applied to the perforated tissue, were run for each taxon. Data were transformed [sqrt (x)] and subjected to analysis of variance (version 6.10; SAS). Mean separation was accomplished using Fisher's protected LSD test.

\section{Results and Discussion \\ Levels of resistance among Buddleia taxa}

LEAF DISK BIOASSAY. The leaf disk bioassay indicated a range of susceptibility to the two-spotted spider mite among Buddleia taxa. The number of mites remaining on leaf disks and the number of eggs laid after 48 and $96 \mathrm{~h}$ provided similar resistance differences among taxa (Table 1). The number of eggs laid on leaf disks after $96 \mathrm{~h}$ was used to select taxa for further evaluation. More susceptible Buddleia taxa included many less pubescent taxa such as $B$. 
Table 4. Predators per $6 \mathrm{~cm}^{2}$ on Buddleia taxa from 8 May until 13 June field trials (error $\mathrm{df}=2148, \mathrm{~F}=3.91, P<0.01$ for averages).

\begin{tabular}{|c|c|c|c|c|c|c|}
\hline \multirow[b]{2}{*}{ Cultivar } & \multicolumn{6}{|c|}{ Predators per $6 \mathrm{~cm}^{2}$ (no.) } \\
\hline & 8 May & 14 May & 25 May & 3 June & 13 June & Avg \\
\hline Gloster $^{\mathrm{y}}$ & $0 \mathrm{a}^{\mathrm{z}}$ & $0.15 \mathrm{a}$ & $0.35 \mathrm{a}$ & $0.05 \mathrm{a}$ & $0 \mathrm{a}$ & $0.12 \mathrm{a}$ \\
\hline Sungold ${ }^{\mathrm{x}}$ & $0 \mathrm{a}$ & $0 \mathrm{~b}$ & $0.23 \mathrm{ab}$ & $0.13 \mathrm{a}$ & $0 \mathrm{a}$ & $0.09 \mathrm{a}$ \\
\hline Bonnie $^{w}$ & $0.04 \mathrm{a}$ & $0 \mathrm{~b}$ & $0.10 \mathrm{bc}$ & $0.05 \mathrm{a}$ & $0.10 \mathrm{a}$ & $0.07 \mathrm{ab}$ \\
\hline Pink Delight $^{\mathrm{w}}$ & $0 \mathrm{a}$ & $0.03 \mathrm{~b}$ & $0.08 \mathrm{bc}$ & $0.05 \mathrm{a}$ & $0.05 \mathrm{a}$ & $0.04 \mathrm{ab}$ \\
\hline African Queen ${ }^{w}$ & $0 \mathrm{a}$ & $0 \mathrm{~b}$ & $0.03 \mathrm{bc}$ & $0.13 \mathrm{a}$ & $0 \mathrm{a}$ & $0.04 \mathrm{ab}$ \\
\hline Cornwall Blue $^{v}$ & $0 \mathrm{a}$ & $0 \mathrm{~b}$ & $0 \mathrm{c}$ & $0.10 \mathrm{a}$ & $0.08 \mathrm{a}$ & $0.04 \mathrm{ab}$ \\
\hline Nanho White ${ }^{\mathrm{w}}$ & $0 \mathrm{a}$ & $0.03 \mathrm{~b}$ & $0.03 \mathrm{bc}$ & $0.03 \mathrm{a}$ & $0.03 \mathrm{a}$ & $0.03 \mathrm{~b}$ \\
\hline Ile de France ${ }^{w}$ & $0 \mathrm{a}$ & $0 \mathrm{~b}$ & $0.03 \mathrm{bc}$ & $0.03 \mathrm{a}$ & $0 \mathrm{a}$ & $0.03 \mathrm{~b}$ \\
\hline Black Knight ${ }^{w}$ & $0 \mathrm{a}$ & $0 \mathrm{~b}$ & $0.08 \mathrm{bc}$ & $0 \mathrm{a}$ & $0 \mathrm{a}$ & $0.02 \mathrm{~b}$ \\
\hline Miss Ellen ${ }^{w}$ & $0 \mathrm{a}$ & $0 \mathrm{~b}$ & $0 \mathrm{c}$ & $0.10 \mathrm{a}$ & $0 \mathrm{a}$ & $0.02 \mathrm{~b}$ \\
\hline Alba $^{u}$ & $0 \mathrm{a}$ & $0 \mathrm{~b}$ & $0.03 \mathrm{bc}$ & $0 \mathrm{a}$ & $0 \mathrm{a}$ & $0.01 \mathrm{~b}$ \\
\hline
\end{tabular}

${ }^{\mathrm{z}}$ Means in a column followed by the same letter are not significantly different ( $\alpha=0.05$ level) using Fisher's protected LSD test.

y Buddleia lindleyana.

${ }^{\mathrm{x}}$ Buddleia weyeriana.

${ }^{w}$ Buddleia davidii.

${ }^{\vee}$ Buddleia davidii $\times$ B. fallowiana.

"Buddleia fallowiana.

lindleyana and $B$. japonica while resistant taxa generally included more pubescent taxa such as $B$. fallowiana 'Alba' and B. davidii $\mathrm{X}$ B. fallowiana 'Cornwall Blue', thus revealing a possible cause for differences in spider mite susceptibility.

The exit of mites from leaf surfaces onto petroleum jelly was consistent with other research where mites departed leaf disks despite the presence of viscous compounds (Aina etal., 1972; Knipping et al., 1975; Mansour and Karchi, 1990; Wilde et al., 1991), but inconsistent with others where mites remained on leaf disks (East et al., 1992; Soans et al., 1973). The exit of mites from leaf disks is a nonpreference effect (Knipping et al., 1975) and may be considered to have little effect on a natural population of two-spotted spider mites if plants are separated (de Ponti, 1977a) or if plants are raised in a monoculture (de Ponti, 1977b) and so was not considered a major factor when considering Buddleia taxa for further evaluation.

Shell VIAL BIOASSAY. Differences between and among resistant and susceptible taxa via the shell vial bioassay (Table 2) were essentially consistent with, though better defined than, results from the preliminary leaf disk bioassay. Eggs were laid primarily on leaf surfaces although some eggs were laid along the lip of shell vials. Differences in number of eggs laid per shell vial among taxa indicate gradients of resistance to the two-spotted spider mite among Buddleia taxa. The greatest number of eggs per shell vial were laid on the lower surface of Buddleia davidii 'African Queen' indicating a high degree of susceptibility to infestation by the twospotted spider mite. The Buddleia taxa that showed the greatest resistance to two-spotted spider mite infestation, based on number of eggs laid per shell vial, were $B$. fallowiana Balif. 'Alba' and $B$. davidii x B. fallowiana 'Cornwall Blue' (Table 2) which had 7\% and $14 \%$, respectively, of the number of eggs laid on 'African Queen'. That 'Cornwall Blue', a cross between B. davidii and B. fallowiana, was one of the more resistant Buddleia indicates that Buddleia taxa could be hybridized to confer two-spotted spider mite resistance.

Field TRIAL. Field trials showed increased spider mite populations from early May until mid June (Table 3). After 13 June, spider mite populations declined abruptly and never rose above one twospotted spider mite per block. Beneficial arthropods found within sampled areas included predatory mites, spiders, lady beetles, and lacewings. Beneficial arthropod numbers followed a trend similar to two-spotted spider mite numbers (Table 4). It is not known whether predator numbers were highest on plants that were less resistant to spider mites due to larger quantities of spider mites, or to a lack of resistance factors which might affect predators on twospotted spider mite resistant taxa. Buddleia lindleyana 'Gloster' maintained the highest average concentration of two-spotted spider mites from 8 May until 13 June. It is suspected that the reason for larger two-spotted spider mite populations on $B$. lindleyana 'Gloster' is that $B$. lindleyana is a semievergreen species and mites may overwinter in situ and initiate feeding and egg laying earlier in the season. Of the deciduous taxa, 'African Queen' and 'Sungold' maintained the highest concentrations of mites and eggs while $B$. fallowiana 'Alba' had the lowest concentration.

Two-spotted spider mites and eggs counted per $6 \mathrm{~cm}^{2}$ leaf area per day on each taxon confirmed the results of the shell vial bioassay for deciduous Buddleia taxa. The ability of laboratory bioassays to predict field populations of spider mites is generally good (Rodriguez et al., 1983; Stoner and Stringfellow, 1967; Wilde et al., 1991), although each case in which a laboratory test is used to predict field populations must be examined separately due to inherent deviations in conditions between laboratory and field situations (de Ponti, 1977a). The relationship between the average number of mites per $6 \mathrm{~cm}^{2}$ per day on deciduous taxa in field trials (8 May to 14 June) and average numbers of eggs laid

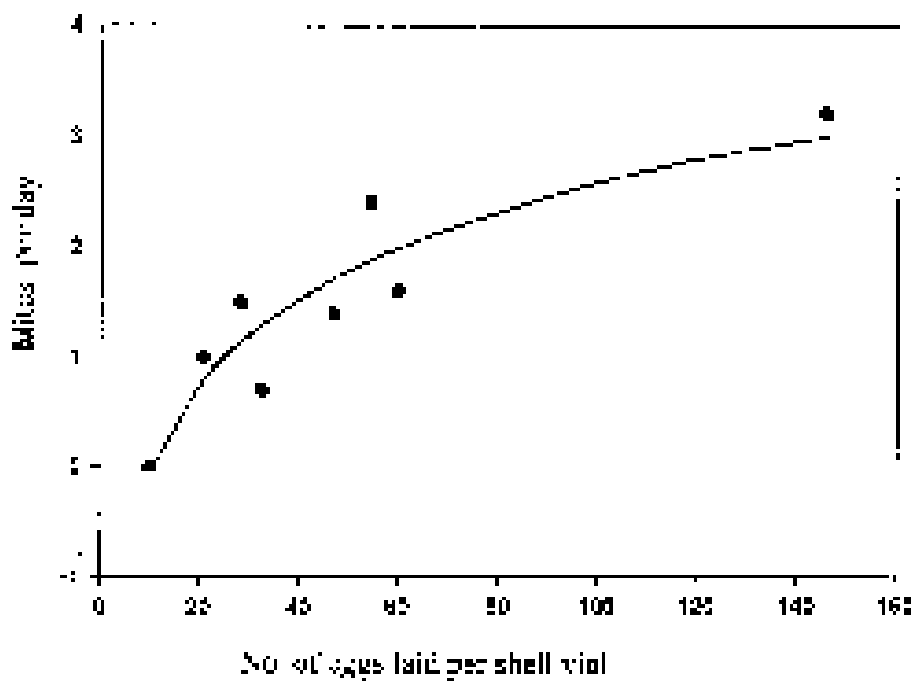

Fig. 2. Relationship between average number of two-spotted spider mites collected per day on an area $6 \mathrm{~cm}^{2}$ in field plots and average number of two-spotted spider mite eggs laid per shell vial for eight deciduous Buddleia taxa. $y=-2.49+1.11(\ln$ $x) ; r^{2}=0.89$, df $=6, \mathrm{~F}=47.0, P<0.01$. 
Table 5. Trichome characteristics (trichome lengths, branches per square millimeter, and effective branch length) of nine Buddleia taxa (error df $=865 ;$ branch length $\mathrm{F}=248.51, P<0.01$; branches per $\mathrm{mm}^{2} \mathrm{~F}=89.29$, $P<0.01 ; \mathrm{EBL} \mathrm{F}=99.55, P<0.01)$.

\begin{tabular}{lccc}
\hline Taxa & $\begin{array}{c}\text { Branch length } \\
(\mathrm{mm})\end{array}$ & $\begin{array}{c}\text { Branches/ } \\
\mathrm{mm}^{2}\end{array}$ & $\begin{array}{c}\mathrm{EBL} \\
\left(\mathrm{mm} \cdot \mathrm{mm}^{-2}\right)\end{array}$ \\
\hline B. fallowiana Balif. Alba & $0.399 \mathrm{a}^{\mathrm{z}}$ & $419.9 \mathrm{c}$ & $168 \mathrm{a}$ \\
B. davidii $\mathrm{X}$ B. fallowiana & & & \\
$\quad$ Cornwall Blue & $0.357 \mathrm{~b}$ & $398.3 \mathrm{~cd}$ & $142 \mathrm{~b}$ \\
B. davidii Miss Ellen & $0.280 \mathrm{c}$ & $395.3 \mathrm{~d}$ & $111 \mathrm{c}$ \\
B. davidii Ile de France & $0.197 \mathrm{e}$ & $524.5 \mathrm{a}$ & $103 \mathrm{~cd}$ \\
B. davidii Black Knight & $0.211 \mathrm{e}$ & $475.2 \mathrm{~b}$ & $100 \mathrm{~d}$ \\
B. weyeriana Weyer Sungold & $0.345 \mathrm{~b}$ & $278.4 \mathrm{f}$ & $96 \mathrm{~d}$ \\
B. davidii Nanho White & $0.260 \mathrm{~d}$ & $321.4 \mathrm{e}$ & $84 \mathrm{e}$ \\
B. lindleyana Gloster & $0.074 \mathrm{~g}$ & $772.8 \mathrm{a}$ & $57 \mathrm{f}$ \\
B. davidii African Queen & $0.170 \mathrm{f}$ & $229.2 \mathrm{~g}$ & $39 \mathrm{~g}$ \\
\hline ZMeans in a column followed by the same letter are not significantly
\end{tabular}

$\overline{{ }^{\mathrm{z}} \text { Means in a column followed by the same letter are not significantly }}$

Correlation coefficients between egg laying data from the preliminary leaf disk bioassay and the average number of mites per $6 \mathrm{~cm}^{2}$ per day counted in the field $\left(r^{2}=0.14\right)$ were not as high as those between the shell vial bioassay and field data. The shell vial bioassay provided a more realistic test mechanism for assessing two-spotted spider mite resistance, as measured by fecundity, than the standard leaf disk bioassay because of a reduction in experimental error caused by viscous materials surrounding leaf disks and because of the orientation of leaves in a natural position for spider mite feeding. The shell vial bioassay system is easy to construct and provides legitimate results thus making it a viable alternative bioassay method for assessing two-spotted spider mite resistance in Buddleia taxa, and potentially in other taxa.

\section{Resistance mechanisms}

QuANTIFICATION OF PUbescence. Pubescence was quantified by analyses of trichome branching and length and is expressed as $\mathrm{mm}$ trichome branches $/ \mathrm{mm}^{2}$ leaf surface area, or effective branch length (EBL). EBL measurements separated taxa by their relative quantities of
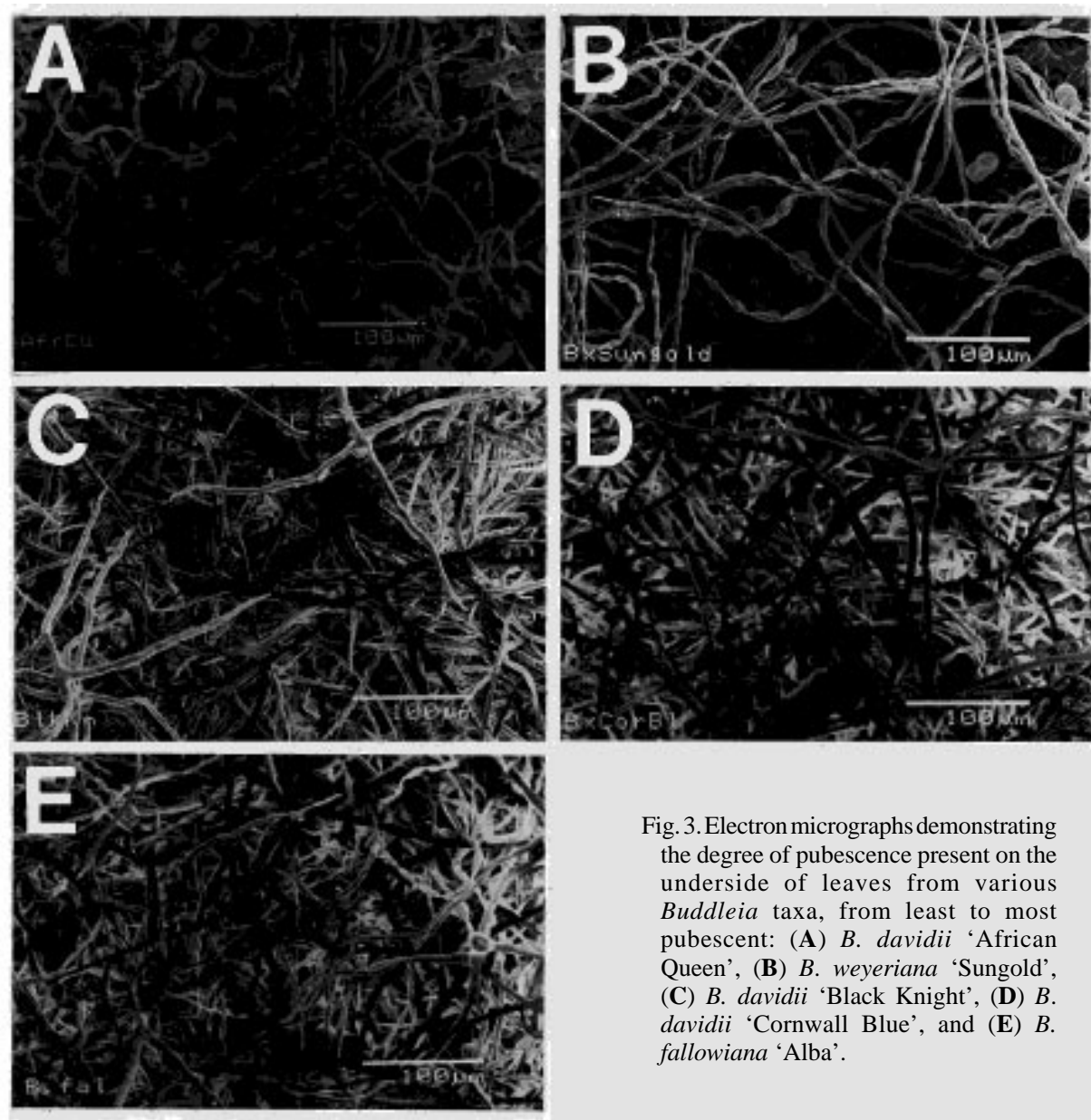
pubescence (Table 5). Analyses of trichome branch lengths and densities using an electron microscope confirmed data collected using light microscopy as well as showing glandular trichomes not observed with light microscopy (Fig. 3). Plotting EBL versus number of eggs laid in the shell vial bioassay (Table 2 ) resulted in a $1 /$ (square root EBL $)$ correlation $\left(r^{2}=0.55\right)$ demonstrating that more pubescent taxa (higher EBL) have fewer eggs laid on them than less pubescent taxa (Fig. 4). This result indicates that the quantity of pubescence present on Buddleia taxa can be used to predict two-spotted spider mite resistance. The fact that $B$. davidii $\times$ B. fallowiana 'Cornwall Blue' had the second greatest EBL, after B. fallowiana 'Alba', corroborates the hypothesis that resistance in Buddleia, correlated with EBL, is heritable.

Removal of PUbescence. Removal of pubescence with facial peel resulted in an increase in oviposition for Buddleia davidii 'Black Knight' and B. davidii 'Cornwall Blue' (Table 6). This data supports the conclusion above, that increasing levels of pubescence result in lower mite fecundity. Removal of pubescence for assays against arthropod pests has, in the past, been accomplished using a razor blade (e.g., Hoffman and McEvoy, 1986) or other mechanical means to scrape the leaf surface. Removal of pubescence by scraping,

different $(\alpha=0.05)$ using Fisher's protected LSD test. after $96 \mathrm{~h}$ in the shell vial bioassay (Fig. 2) was observed. The high correlation $\left(r^{2}=0.89\right)$ between data from the shell vial bioassay and the field trial supports the conclusion that the shell vial bioassay is a valid means of predicting the resistance of a Buddleia taxon to infestation by the two-spotted spider mite. Buddleia lindleyana 'Gloster' was not included in this correlation because of the confounding effect of a semi-evergreen species and should be expected to develop larger infestations of the two-spotted spider mite than deciduous taxa. however, has the unfortunate side effect of damaging epidermal layers when trichomes are small. Advantages of using a A peel technique included minimal damage to leaf surfaces and almost complete pubescence removal. All pubescence was successfully removed from interveinal areas using facial peel, however, at the intersection of veins, there was frequently a small area of pubescence, $\approx 1 \mathrm{~mm}^{2}$, that remained.

The decrease in two-spotted spider mite egg laying associated with increasing pubescence levels of Buddleia is consistent with 


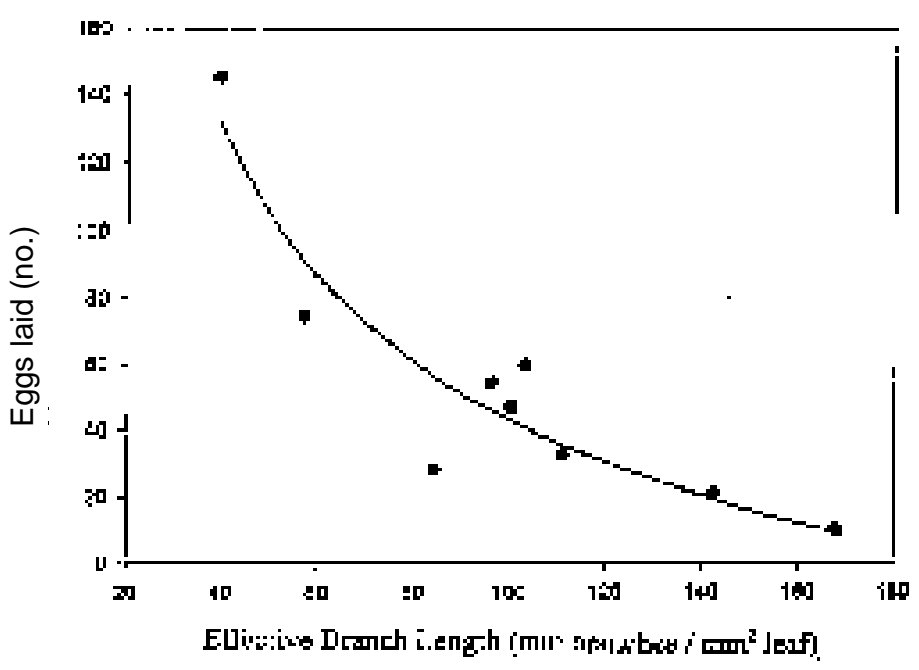

Fig. 4. Relationship between number of two-spotted spider mite eggs laid (five female mites, $96 \mathrm{~h}$ ) in a shell vial bioassay and effective branch length (EBL) (mm trichome branches per square millimeter of leaf surface area) of nine Buddleia taxa. $y=-104.98+1478.83(1 / \operatorname{sqrt} x) ; r^{2}=0.55$, error $\mathrm{df}=36, \mathrm{~F}=41.7, P<0.01$.

findings in other crops including beach strawberry, Fragaria chiloensis Duch., where an increase in density of nonglandular trichomes decreased the number of eggs laid by the two-spotted spider mite (Luczynski et al., 1990) and cotton, Gossypium hirsutum L., where tall, highly branched trichomes conferred twospotted spider mite resistance (Kamal and Elkassaby, 1965). In other crops, however, nonglandular trichomes have decreased resistance to the two-spotted spider mite. High densities of nonglandular trichomes increase two-spotted spider mite oviposition in hops, Humulus lupulus L., although mites do not necessarily show a preference for these more pubescent varieties (Peters and Berry, 1980). Likewise, Fragaria ×ananassa Duch. cultivars which are more pubescent tend to be more susceptible to attack by the two-spotted spider mite (Kishaba et al., 1972). Apple (Malus $\times$ domestica Borkh.) varieties with higher densities of trichomes are also more susceptible to infestations of $T$. urticae than less pubescent varieties (Yiem et al., 1993).

EFFECT OF LEAF SURFACE COMPOUNDS ON TWO-SPOTTED SPIDER MITE FECUNDITY. The modified shell vial bioassay forced mites to contact leaf surface extracts from experimental plants when mites fed or oviposited on the lower surface of the bean leaf. Methylene chloride extract from the more pubescent 'Cornwall Blue' resulted in an average of $43.0 \mathrm{eggs}$ laid per shell vial. This was significantly less than the average of 98.4 eggs laid per shell vial when only methylene chloride was added to the tissue. Mites exposed to extract from 'African Queen' laid an average of 72.8 eggs per shell

Table 6. Effect of pubescence removal on the number of eggs laid per shell vial by five female two-spotted spider mites incubated with leaves from Buddleia cultivars (error $\mathrm{df}=17$; 'African Queen' $\mathrm{F}=1.65, P=$ 0.22 ; 'Cornwall Blue' $\mathrm{F}=6.83, P<0.01$; 'Black Knight' $\mathrm{F}=12.53, P$ $<0.01$; 'Miss Ellen' $\mathrm{F}=2.08, P=0.16$ ).

\begin{tabular}{lcccc}
\hline \hline \multicolumn{5}{c}{ B. davidii } \\
Treatment & B. davidii & $\times$ B. fallowiana & B. davidii & B. davidii \\
Aeeled & $155.0 \mathrm{a}^{\mathrm{z}}$ & $75.9 \mathrm{a}$ & $60.0 \mathrm{a}$ & $14.2 \mathrm{a}$ \\
Nonpeeled & $108.7 \mathrm{a}$ & $43.5 \mathrm{~b}$ & $16.4 \mathrm{~b}$ & $8.3 \mathrm{a}$ \\
\hline
\end{tabular}

$\overline{{ }^{\mathrm{z}} \text { Means in a column followed by the same letter are not significantly }}$ different $(\alpha=0.05)$ using Student's $t$ test. vial which was statistically similar to 'Cornwall Blue' and the control. Buddleia species have glandular trichomes (Rogers, 1986) whose constitutory compounds are unknown but which may affect the two-spotted spider mite in a deleterious way.

The identification of two-spotted spider mite resistant Buddleia taxa indicates that progeny could be bred for greater resistance. Resistance to the two-spotted spider mite in Buddleia taxa is correlated with a particular taxon's quantity of nonglandular pubescence, thus making quantity of pubescence an effective indicator of practical resistance to the two-spotted spider mite. There is also evidence to indicate that chemical constituents are present on the surface of leaves, and potentially in trichomes, which affect the ability of two-spotted spider mites to infest a given Buddleia taxon. The commercial production of Buddleia taxa that are more resistant to the two-spotted spider mite would reduce aesthetic damage and pesticide inputs required to grow this crop.

\section{Literature Cited}

Aina, O.J., J.G. Rodriguez, and D.E. Knavel. 1972. Characterizing resistance to Tetranychus urticae in tomato. J. Econ. Entomol. 65:641-643.

Baker, J. R. 1980. Insects and related pests of shrubs. N.C. Coop. Ext. Serv. Publ. AG-189.

Chin, S.F., S. Lin, and C.Y. Hu. 1947. Toxicity study of insecticidal plants in southwest China. Chem. Abstr. 41:2201-2202.

de Ponti, O.M.B. 1977a. Resistance in Cucumis sativus L. to Tetranychus urticae Koch. 2. Designing a reliable laboratory test for resistance based on aspects of the host-parasite relationship. Euphytica 26:641-654.

de Ponti, O.M.B. 1977b. Resistance in Cucumis sativus L. to Tetranychus urticae Koch. 1. The role of plant breeding in integrated control. Euphytica 26:633-640.

Dirr, M.A. 1998. Manual of woody landscape plants. Stipes Publishing Co., Champaign, Ill.

East, D.A., J.V.Edelson, E.L. Cox, and M.K. Harris. 1992. Evaluation of screening methods and search for resistance in muskmelon, Cucumis melo L., to the two-spotted spider mite, Tetranychus urticae Koch. Crop Prot. 11:39-44.

Ferrer, R.M.G., J.C. Scheerens, and W.A. Erb. 1993. In vitro screening of 76 strawberry cultivars for two-spotted spider mite resistance. HortScience 28:841-844.

Herron, G., L. Jiang, and R. Spooner-Hart. 1996. A laboratory-based method to measure relative pesticide and spray oil efficacy against broad mite, Polyphagotarsonemus latus (Banks) (Acari: Tarsonemidae). Expt. Appl. Acarol. 20:495-502.

Hoffman, G.D. and P.B. McEvoy. 1986. Mechanical limitations on feeding by meadow spittlebug, Philaenus spumarius (Homoptera: Cercopidae), on wild and cultivated host plants. Ecol. Entomol. 11:415426.

Hudson, W.G., S.K. Braman, R.D. Oetting, and B.L. Sparks. 1996. Ornamental, lawn, and turf insects, p. 20-22. In: R.M. McPherson, G.K. Douce, and D.G. Riley (eds.). Summary of losses from insect damage and costs of control in Georgia 1995. Ga. Agr. Expt. Sta. Spec. Publ. 90.

Kabir, K.H., R.B. Chapman, and D.R. Penman. 1996. Miticide bioassays with spider mites (Acari: Tetranychidae): Effect of test design and sample size on the precision of lethal concentration estimates. Expt. Appl. Acarol. 20:483-494.

Kamal, S.A. and F.Y. Elkassaby. 1965. Relative resistance of cotton varieties to spider mites, leafhoppers, and aphids. J. Econ. Entomol. 58:209-212.

Kishaba, A.N., V. Voth, A.F. Howland, R.S. Bringhurst, and H.H. Toba. 1972. Two-spotted spider mite resistance in California strawberries. J. Econ. Entomol. 65:117-119.

Knipping, P.A., C.G. Patterson, D.E. Knavel, and J.G. Rodriguez. 1975. Resistance of curcubits to two-spotted spider mite. Environ. Entomol. 4:507-508.

Luczynski, A., M.B. Isman, D.A. Raworth, and C.K. Chan. 1990. Chemical and morphological factors of resistance against the two-spotted spider mite in beach strawberry. J. Econ. Entomol. 83:564-569. 
Mansour, F. and Z. Karchi. 1990. The evaluation of antibiosis of selected lines for resistance of melon to the carmine spider mite Tetranychus cinnabariensis (Acari: Tetranychidae). Bul. Entomol. Res. 80:345-347.

Maunder, M. 1987. Notes on tender species of Buddleia. The Plantsman 9:64-80.

Metcalf R.L. and R.A. Metcalf. 1993. Destructive and useful insects, 5th ed. McGraw Hill, New York.

Owen, D.F. and W.R. Whiteway. 1980. Buddleia davidii in Britain: History and development of an associated fauna. Biol. Conserv. 17:149155.

Peters, K.M. and R.E. Berry. 1980. Effect of hop leaf morphology on twospotted spider mite. J. Econ. Entomol. 73:235-238.

Roder, E., H. Wiedenfeld, and A. Hoenig. 1985. Isolation of a new tricyclic piperidine alkaloid from Buddleia davidii. Planta Med. 51:164165.

Rodriguez, J.G., D.A. Reicosky, and C.G. Patterson. 1983. Soybean and mite interactions: Effects of cultivar and plant growth stage. J. Kan. Entomol. Soc. 56:320-326.

Rogers, G.K. 1986. The genera of Loganiaceae in the southeastern United States. J. Arnold Arbor. 67:143-185.

Schuster, M.F., F.G. Maxwell, J.N. Jenkins, and W.L. Parrott. 1972. Mass screening seedlings of Gossypium sp. for resistance to the two-spotted spider mite. J. Econ. Entomol. 65:1104-1107.
Shoeb, H.A., A.M. Mousa, M.M. El Sayed, and A.M. Emam. 1991. Laboratory evaluation of some plants as molluscicidal agent. Egypt. J. Bilharziasis. 13:189-194.

Soans, A.B., D. Pimentel, and J.S. Soans. 1973. Resistance in cucumber to the two-spotted spider mite. J. Econ. Entomol. 66:380-382.

Stermitz, F.R. and G.R. Harris. 1985. Reappraisal of the structure for the alkaloid buddamin from Buddleja davidii. Tetrahedron Lett. 26:52515252

Stoner, A.K. and T. Stringfellow. 1967. Resistance of tomato varieties to spider mites. Proc. Amer. Soc. Hort. Sci. 90:324-329.

Wilde, G., W. Thomas, and H. Hall. 1991. Plant resistance to two-spotted spider mite (Acari: Tetranychidae) in raspberry cultivars. J. Econ. Entomol. 84:251-255.

Yiem, M.S., J.H. An, and Y.I. Lee. 1993. Relationships between morphological characteristics of apple leaf and resistance to two-spotted spider mite (Tetranychus urticae Koch). RDA J. Agr. Sci. Hort. 35:464-470.

Yoshida, T., J. Nobuhara, N. Fujii, and T. Okuda. 1978. Studies on the constituents of Buddleia species. II. Buddledin C, D and E, new sesquiterpenes from Buddleia davidii Franch. Chem. Pharm. Bul. 26:2543-2549.

Zhang, X., Y. Xi, W. Zhou, and M. Kay. 1993. Cleopus japonicus, a potential biocontrol agent for Buddleja davidii in New Zealand. N.Z. J. For. Sci. 23:78-83. 